\title{
Patentability of Genes: A European Union Perspective
}

\author{
Paul Cole \\ Bournemouth University, Bournemouth, Dorset BH12 5BB, United Kingdom; and Lucas \& Co, \\ Warlingham, Surrey CR6 9HJ, United Kingdom \\ Correspondence: pcole@lucas-uk.com
}

Unlike the position in the United States following the recent Supreme Court decision in Myriad, in the European Union naturally occurring genetic sequences, whether of human or other origin, remain patent-eligible. Here the basis for such eligibility in legislation and in case law is explained. The utility of a sequence must be disclosed as a condition of eligibility, and requirements outlined in European Patent Office (EPO) and U.K. case law are discussed. A claimed sequence must also satisfy requirements of novelty and inventive step, the latter being considered primarily using the tests of "obvious to try" and reasonable expectation of success. From both positive and negative examples the significance of an identifiable difficulty supported by documentary and/or experimental evidence is apparent. Issues of priority and subject matter added by amendment during prosecution of an application can create unexpected problems given the narrow interpretation within the EPO of the identity of a disclosed sequence, and these problems are explored using as an example an opposition to a European patent covering BRCA1 gene sequences. Practical steps for the drafting of patent specifications to be filed in Europe are outlined.

$\mathrm{T}^{\mathrm{h}}$ he conclusion of the U.S. Supreme Court in Association for Molecular Pathology v. Myriad Genetics, Inc. (569 U.S. 12-398) (2013) is summarized in the proposition that DNA segments and the information that they encode are not patent-eligible under 35 U.S.C. $\$ 101$ simply because they have been isolated from the surrounding genetic material. That finding was made irrespective of whether the DNA segments originate from a human or from another organism and applies indiscriminately to sequences from eukaryotic and prokaryotic organisms.
The position is otherwise in Europe. However, to meet requirements of patent eligibility, the functionality of a genetic sequence or the polypeptide encoded thereby must be disclosed in the application as filed, and detailed requirements are reviewed together with the more usual topics of novelty and inventive step. Issues of priority and added subject matter are of particular sensitivity in Europe. The problems that can arise from basing a European patent on a corrected sequence with omission of an originally disclosed sequence in which, as is tempting for inventors, the decision is taken

Editors: Salim Mamajiwalla and Rochelle Seide

Additional Perspectives on Intellectual Property in Molecular Medicine available at www.perspectivesinmedicine.org

Copyright (C) 2015 Cold Spring Harbor Laboratory Press; all rights reserved; doi: 10.1101/cshperspect.a020891

Cite this article as Cold Spring Harb Perspect Med 2015;5:a020891 
P. Cole

to publish the sequence first and deal with the legal consequences afterwards are explained.

\section{PATENT ELIGIBILITY}

The holding in Myriad that naturally occurring genetic sequences are not patent-eligible merely because they have been isolated has no clear counterpart under either the European Patent Convention (EPC) or the national laws of the individual contracting states. Isolated DNA sequences are patentable under the EPC irrespective of whether or not they are naturally occurring and irrespective of whether or not they are human sequences. For nonhuman sequences, that is the case in all EPC contracting states. For human sequences, the national laws of France and Germany are more stringent, although, as explained below, the validity of that more stringent approach is now doubtful. The relevant national laws are, however, likely to remain untested for the foreseeable future because for human sequences the pragmatic approach is to file via the European Patent Office (EPO).

Many of the arguments that came before the Supreme Court in Myriad were rehearsed in the mid-1990s in an opposition by the European Parliament's Green Party group to a patent granted to the Howard Florey Institute for human $\mathrm{H} 2$-relaxin. ${ }^{1}$ The first instance decision was considered sufficiently significant to warrant publication in the Official Journal EPO. It was held that isolation of relaxin could not be dismissed as a mere discovery; that granting a patent for the protein and the genetic sequences encoding it was not contrary to morality because the patenting of a single human gene had nothing to do with the patenting of human life; and that the attitudes of the public to the patenting of human genes as reported in surveys were unpersuasive because the answers given depended on the context within which the issue was put.

The controlling legislation for biotechnological inventions is now contained in the European Biotechnology Directive ${ }^{2}$ adopted in

${ }^{1}$ Howard Florey Institute's Application/Relaxin (OJ EPO 1995, 388) (V 0008/94).
1998. It was some 10 years in the making, and the intensity of the preliminary debate is reflected in the recitals, which are 56 paragraphs and close to 3000 words long. In contrast, the legislative provisions themselves are relatively brief and straightforward.

Article 1 provides that member states should protect biotechnological inventions under national patent law and should, if necessary, adjust their national patent laws to take account of the provisions of the directive. Obligations arising under the TRIPs (Trade-Related Aspects of Intellectual Property Rights) agreement are also mentioned, those obligations including making patents available without discrimination as to field of technology for any inventions that are new, involve an inventive step, and are capable of industrial application. As explained by the European Court of Justice (ECJ) in Monsanto Technology v. Cefetra BV (European Court (Grand Chamber), Case C-428/08) (2010), the provisions of the TRIPs Agreement do not create rights upon which individuals may themselves directly rely before the courts. However, European Union rules will be interpreted so far as possible in keeping with that agreement.

Article 2 defines "biological material" to mean any material containing genetic information and capable of reproducing itself or being reproduced in a biological system. It therefore covers nucleotide sequences including fulllength genes, complementary DNA (cDNA), and fragments thereof.

Patentability of biological material in general is provided by Article 3, which confirms that novel, inventive, and industrially applicable (broadly corresponding to "useful" in 35 USC \$101) inventions are protectable by patents even if they concern a product consisting of or containing biological material or a process by means of which biological material is produced, processed, or used. In particular, biological material that is isolated from its natural environment or produced by means of a tech-

\footnotetext{
${ }^{2}$ Directive 98/44/EC of the European Parliament and of the Council of 6 July 1998 on the legal protection of biotechnological inventions (OJ EC L 213/13) (30.7.98).
} 
nical process may be the subject of an invention even if it previously occurred in nature.

For biological material from the human body, Article 5 provides that the simple discovery of the sequence or partial sequence of a gene cannot constitute a patentable invention. However, the sequence or partial sequence of a gene isolated from the human body or otherwise produced by means of a technical process may constitute a patentable invention even if its structure is identical to that of a natural element. As a condition for patentability, the industrial application of a sequence or a partial sequence of a gene must be disclosed in the patent application.

An application to the European Court for annulment of the directive in the Kingdom of the Netherlands v. Council of the European Union (European Court, Case C-377/97) (2001) was rejected. The court held that by requiring the member states to cover biotechnological inventions in their national patent laws, the directive prevented damage to the unity of the internal market from the member states' deciding unilaterally to grant or refuse such protection. There was nothing to suggest that such an approach was inconsistent with their honoring their obligations under the EPC. The court explained that the directive covers national patents issued in accordance with the procedures applicable in the member states and deriving their protective force from national law. The court also drew attention to the strict conditions for patentability set out in the directive. In particular, the sequence or partial sequence of a human gene can only give rise to the grant of a patent if the application is accompanied by both (1) a description of the original method of sequencing that led to the invention and (2) an explanation of the industrial application to which the work is to lead. In the absence of an application in that form, there would be no invention, but rather the discovery of a DNA sequence, which would not be patentable as such.

In Monsanto the ECJ pointed out that Article 1(1) of the directive requires member states to protect biotechnological inventions under their national patent laws and to make adjustments in accordance with the provisions of the directive. Accordingly, the harmonization effected by Article 9 of the directive (which refers to scope) should be regarded as exhaustive and precludes national legislation from producing a different effect. It will be apparent that the same argument is equally applicable to Articles 3 and 5 and is consistent with the ruling in the Kingdom of the Netherlands case.

The EPO incorporated the provisions of Articles 3 and 5 of the directive into the Implementing Regulations to the EPC without modification as EPC 2000 Rules 27 and 29. These rules now provide legislative authority for the patent eligibility of claims to isolated nucleotide sequences covering naturally occurring genes under the EPC, and that the resulting patents can be brought into effect in all EPC contracting states.

Further confirmation of the patent eligibility of isolated nucleotide sequences of both humans and other organisms is provided by decisions of the EPO Boards of Appeal in the course of opposition proceedings. In a landmark decision in the Relaxin case, ${ }^{3}$ an appeal board explained that these rules merely interpret existing law and that claims to DNAs encoding the human protein preprorelaxin that are obtained by technical processes are patent-eligible and do not fall within the category of alleged inventions that are excluded from protection as mere discoveries. The reasoning in that case was affirmed in the BRCA1 sequences case ${ }^{4}$ concerning a claim to DNA encoding the BRCA1 gene and corresponding to the '282 patent at issue in Myriad. The appeal board treated as irrelevant any economic effects flowing from patent grant because there was no basis in the EPC for distinguishing between inventions in different technical fields (echoing the provisions of the TRIPs agreement) and because the exclusionary nature of the rights granted was the same for all patents.

European patents with claims to genes and proteins encoded by specified nucleotide se-

${ }^{3}$ T 272/95 (Relaxin/HOWARD FLOREY INSTITUTE).

${ }^{4} \mathrm{~T} 1213 / 05$ (Breast and ovarian cancer/UNIVERSITY OF UTAH). 
P. Cole

quences continue to be granted by the EPO, and the following examples are believed representative:

- EP-B-2155219 (United States of America as represented by the Secretary of Agriculture) for an isolated or recombinant DNA molecule encoding a polypeptide of listed amino acid sequence that is responsible for the AltSB locus for aluminum tolerance in Sorghum bicolor, granted on February 19, 2014.

- EP-B-2311468 (Perseus Proteomics) for a gene and protein useful in the treatment of bone cancer, granted on January 15, 2014.

- EP-B-2129781 (Novozymes) for an isolated polypeptide having phytase activity and an isolated nucleotide sequence that encodes it, granted January 22, 2014.

- EP-B-2028278 (Whitehead Institute for Biomedical Research) for isolated doublestranded RNA of from 21 to 23 nucleotides in length in the form of two separate RNA strands, perfectly complementary to an mRNA and mediating RNA interference by directing cleavage of the mRNA to which it is perfectly complementary, granted March 19, 2014.

- EP-B-2021362 (Innoventus) for an isolated and purified structural gene encoding a fluorescent protein, granted January 8, 2014.

- EP-B-1668029 (International Livestock Research Institute, Kenya) for sequences useful, for example, as probes for tick-borne diseases in cattle and other animals and for the production of vaccines, granted December 25, 2013.

In some cases applicants prefer to claim a construct (e.g., a plant containing the genetic sequence). For example, EP-B-1947925 (CSIRO) relating to a wheat plant comprises a genetic variation that modifies ABA 8'-hydroxylase activity in the seed of the plant and decreases the rate of germination.

Implementation of the Biotechnology Directive in German national law followed extended debate, but that debate only proved significant for human genes. For genetic sequences from other organisms, the practice of the German Patent Office is to allow patents with claims covering isolated DNA, and the following examples are believed representative:

- DE-B-19983297 (Flament D. et al; U.S. Patent No. 6,511,838 corresponds) granted July 4, 2013, covering naturally occurring gene sequences from a marine bacterium coding for a $\beta$-agarase.

- DE-B-10149715 (Schwab H. et al.) granted April 18, 2013, covering polynucleotides from the bacterium Rhodococcus ruber and encoding an esterase; also covering short sequences.

- DE-B-102004386 (Chen Y. et al.; U.S. Patent No. 7,482,157 corresponds) granted in June 2010 having as its object the provision of genes related to the production of monacolin $\mathrm{K}$ (a naturally occurring statin also known as lovastatin) from the mold Monascus. The claims cover an isolated DNA molecule comprising a polynucleotide relating to $\mathrm{mkA}$ and encoding a polypeptide having an activity selected from $\beta$-ketoacyl synthase, acetyltransferase, dehydratase, methyltransferase, and ketoreductase.

For human genes, 1 1a of the German Patent Act as amended in March 2005 provides at $\$ 4$ :

Where the subject matter of an invention is a sequence or a partial sequence of a gene, the structure of which is identical to the structure of a natural sequence or partial sequence of a human gene, the use thereof, for which industrial application is specifically described in subsection (3), shall have to be included in the patent claim.

In 2006, Christoph Ann (Ann 2006) argued that $\$ 4$ is inapplicable to patents granted by the EPO because the EPO and national patents are independent of one another, so that for inventions involving human gene sequences or parts thereof European patents are more accessible than German patents. In these circumstances he viewed $\$ 4$ as no more than symbolic. The position has since become further clarified by the Monsanto decision, which as mentioned above puts forward principles of exhaustive 
harmonization with which $\$ 4$ is arguably incompatible. ${ }^{5}$

The French Patents Act was amended similarly to that in Germany and is not believed to require individual discussion.

\section{INDUSTRIAL APPLICABILITY}

As explained above, an essential condition for grant of a patent for a genetic sequence is that industrial applicability must be disclosed in the application as filed.

It has been held that under Article 57 EPC it is necessary to disclose in definite technical terms the purpose of an invention and how it can be used in industry to solve a given technical problem, ${ }^{6}$ this being the actual benefit or advantage of the invention. The fact that a function has been predicted by computer-assisted methods, rather than on the basis of traditional wetlab techniques, does not mean that it has to be automatically disregarded or excluded from examination, and probative value has to be examined on a case-by-case basis. The function of a protein (and thus of the nucleic acid encoding it) can be seen at different levels, which include its molecular function, its cellular function, and its broad biological function. The elucidation of one of these levels of function could result in a straightforward industrial application, even though the other levels of activity remain completely unknown or only partially characterized. For the purpose of Article 57 EPC and Rules 23(e)(3) and 27(1)(f) EPC, none of these levels is more fundamental than the others.

Human Genome Sciences Inc ${ }^{7}$ (HGS), which is a leading authority on this subject, considered industrial application for a protein called neutrokine- $\alpha$ and its genetic sequence identified by data mining techniques. Although the protein belongs to the tumor necrosis factor (TNF) ligand superfamily, its function in the body was incompletely understood. Objections of lack of

\footnotetext{
${ }^{5}$ That is also the view of Gold and Carbone (2010), which has been cited by several authors. Although the main article is available online, the appendix, unfortunately, is not. ${ }^{6} \mathrm{~T}$ 0898/05 (Hematopoietic receptor/ZYMOGENETICS). ${ }^{7}$ [2011] UKSC 51.
}

industrial applicability were rejected in European opposition proceedings, ${ }^{8}$ and the same decision was reached by the Supreme Court (UK) in subsequent proceedings concerning the European patent in its national phase.

In the U.K. litigation, the principles adopted by the EPO Board of Appeal were reviewed by the Supreme Court (UK), which held that a patent must disclose "a practical application" and "some profitable use" for the claimed substance and that a merely speculative statement of use would not suffice. Merely identifying the structure of a protein, without attributing to it a clear role, or suggesting any practical use for it was not enough. However, a "plausible" or "reasonably credible" claimed use, or an "educated guess," could suffice. 9 Such plausibility could be confirmed by postfiling evidence, although postfiling evidence on its own would not suffice. ${ }^{10}$

Where the protein is said to be a family or superfamily member, if all known members have a known function (e.g., a role in the proliferation, differentiation, and/or activation of immune cells or a function in controlling physiology, development, and differentiation of mammalian cells), assigning a similar role to the protein may suffice and the problem to be solved in such a case can be isolating a further member of the family. If the disclosure is important to the pharmaceutical industry, the disclosure of the sequences of the protein and its gene may suffice. The individual proteins need not always be precisely interchangeable in terms of their biological action, and it may be sufficient if most of them have a common role. ${ }^{11}$ The position may be different if there is evidence, either in the patent or elsewhere, that calls the claimed role or membership of the family into question, or if the known members have different activities.

In HGS, the disclosure of the existence and structure of neutrokine- $\alpha$ and its gene sequence

\footnotetext{
${ }^{8} \mathrm{~T}$ 0018/09 (Neutrokine/HUMAN GENOME SCIENCES).

${ }^{9} \mathrm{~T} 1329 / 04-6$ and 11; T 0640/04 6; T 0898/05 8, 21, 27, and 31; T 452/06 $\$ 6$; and T 1165/06 $\$ 25$.

${ }^{10} \mathrm{~T} 1329 / 04-12 ; \mathrm{T} 0898 / 05-24 ; \mathrm{T} 1452 / 06 \bullet 6$; and $\mathrm{T}$ $1165 / 06-25$.

${ }^{11} \mathrm{~T} 0870 / 04-12$; T 0604/04 $\uparrow 16$; and T 0898/05 $\ 27$.
} 
P. Cole

and its membership of the TNF ligand superfamily were sufficient, taking into account the common general knowledge, to satisfy the requirements of Article 57 EPC. Where all known members of the superfamily manifest common activities to a significant degree, it would be strange if the fact that they had additional but differing qualities precluded the grant of such a patent. The disclosure of a new member would not only be of greater potential value than if the additional qualities did not exist, but the reason for the grant of the patent is the perceived value of a new member because of the common features of all known members, which remains unaffected by the additional qualities. The fact that further work was required to see whether the new member actually had therapeutic benefits did not, at least without more, undermine the validity of a patent. The dividing line between "plausibility" and "educated guess," as against "speculation," just like the contrast between "a real as opposed to a purely theoretical possibility of exploitation," could be difficult to discern in terms of language and application and was a point on which tribunals could differ. However, the patent in issue fell on the qualifying side of the line.

Further guidance is found in the opinion of the EPO Board of Appeal in HGS. When dismissing the opposition, the board found that the undisputed structural identification of neutrokine- $\alpha$ as a member of the TNF ligand superfamily in combination with the disclosed mRNA expression supported its presence on activated $\mathrm{T}$ cells and its ability to costimulate Tcell proliferation. A skilled reader would have distinguished such positive technical information from other allegedly contradictory and speculative statements. The skilled reader would have realized that the description of the structure of neutrokine- $\alpha$, its structural assignment to the family of TNF ligands, and the reports about its tissue distribution and activity on leukocytes were essential steps at the beginning of research on the newly found superfamily member that the skilled reader would have appreciated were necessary. The long list of possible actions of neutrokine- $\alpha$ and of medical conditions in which it might take part would be in- terpreted as the enumeration or generalization of the properties of the members of the TNF ligand superfamily. Filing patents with such long lists of conditions and activities and subsequently relying on the few that have been confirmed or demonstrated had been criticized by the opponents as a "boilerplate" and "cherrypicking" practice. However, the skilled reader was acquainted with this practice and could distinguish mere "boilerplate" from positive technical information.

\section{NOVELTY}

Claims to nucleic acid sequences give rise to relatively few difficulties from the standpoint of the EPC or the laws of the various contracting states as regards novelty.

The principle that to anticipate an earlier disclosure must contain a clear and unmistakable disclosure of the later claimed subject matter applies in biotechnology as in other aspects of patent law. Prior publication of a sequence embedded in the human genome is not prejudicial to the novelty of the sequence claimed in an isolated state; prior disclosure of the isolated sequence does not anticipate the corresponding cDNA that does not occur in nature; and prior disclosure of the cDNA does not anticipate short sequences of special interest. Additionally, to be validly citable for lack of novelty, a prior disclosure must be enabling.

Patentability of newly discovered and isolated genetic sequences and the legitimacy of claiming them in terms of the protein for which they encode are set out in the EPO Guidelines for Examination ${ }^{12}$ and confirmed in an opposition in the following terms ${ }^{13}$ :

It is common ground amongst the parties that until a cDNA encoding human $\mathrm{H} 2$-relaxin and its precursors was isolated by the proprietor, the existence of this form of relaxin was unknown. It is established patent practice to recognise novelty for a natural substance which has been isolated

\footnotetext{
${ }^{12}$ EPO Guidelines for Examination at Part G, Chapter II, 3.1 (www.epo.org/law-practice/legal-texts/html/guidelines/ e/g_ii_3_1.htm).

${ }^{13}$ Howard Florey Institute's Application, supra.
} 
for the first time and which had no previously recognised existence. . .In view of this practice, the novelty of the present claims is assured.

Definition of a genetic sequence by reference to the polypeptide that it encodes has been recognized by the EPO in the above opposition proceedings:

\begin{abstract}
The opponents' assertion that claims $1-4$ are not patentable because the chemical structure of the DNA fragments of those claims is completely undefined cannot be accepted. The DNA is defined in terms of the amino acid sequence it encodes, a generally acceptable terminology and one which is widely used and perfectly understandable to the skilled person. It is true that a very large number of DNA sequences may fall under the scope of the claim, including sequences which possibly occur in nature and differ from those exemplified in the patent. However, this has no bearing on the patentability of the claims...
\end{abstract}

The requirements for an alleged prior use to be accepted as citable prior art are somewhat stringent. Supply of a sample to a third party for sequencing, but without an obligation of confidentiality, does not make the sequence available to the public. ${ }^{14}$ The board held that for a complex biochemical to be made available to the public, the minimum that would be required for publication is a notice to those in the field that samples of the biochemical can be obtained on request and clear evidence of exactly what the biochemical was.

Relevance of gene banks to novelty depends on the level of effort needed to locate a target sequence. The existence of an $\alpha$-interferon (IFN- $\alpha$ ) sequence in Lawn's gene bank has been held not to amount to anticipation ${ }^{15}$ in the absence of a known probe or other means enabling the sequence to be identified. The mere existence of a DNA sequence coding for a polypeptide of the IFN- $\alpha$ type within the multitude of clones of the gene bank did not automatically mean that the polynucleotide concerned became part of the state of the art. That would only happen if the existence of the relevant

${ }^{14} \mathrm{~T}$ 0128/92 (Interleukin-2 polypeptide/AJINOMOTO). ${ }^{15} \mathrm{~T}$ 0301/87 (Alpha-interferons/BIOGEN). polynucleotide had recognizably been made publicly available. Furthermore, interrogation of the gene bank was a biochemical process, and finding a given entity resembled isolation of a component or bacterium from soil. A similar conclusion was reached in relation to erythropoietin. $^{16}$

A different situation arose in Hoffmann-La Roche's Application, ${ }^{17}$ in which a search in the Incyte LifeSeq database for a human protein of interest revealed three clones, the longest of which was missing $\sim 150$ amino acids from the amino terminus, based on homology to the corresponding bovine protein. The database was again searched using the consensus sequence. A large number of clones were identified, including one that appeared to contain the desired full-length coding sequence. It was obtained from Incyte and sequenced, revealing a 689 -amino-acid open reading frame that appeared to encode desired the human protein. Although the cDNA had not been individually indexed in the Incyte library, it could be pinpointed using the associated database without undue burden, and hence anticipation was established.

\section{INVENTIVE STEP}

The evaluation of inventive step in the EPO is conducted using problem/solution analysis and in the United Kingdom is conducted using the Windsurfing/Pozzoli test (Windsurfing v. Tabaur Marine ([1985] R.P.C. 59) and Pozzoli v. BDMO ([2007] EWCA Civ 588)). Cases involving biotechnology are fact-intensive, and when considering past decisions it is advisable to take into account the time frame. For example, the patent for synthetic human tissue plasminogen activator dates from 1982, and its validity was litigated in the United Kingdom in the 1980s. ${ }^{18}$ Although the rules of law applied in that case are of enduring significance, there

\footnotetext{
${ }^{16} \mathrm{~T} 0412 / 93$ (Erythropoietin/KIRIN-AMGEN) at [117].

${ }^{17}$ U.K. Intellectual Property Office, 7 July 2004, BL/O/192/ 04.

${ }^{18}$ Genentech's patent [1987] R.P.C. 553 and [1989] R.P.C. 147.
} 
P. Cole

have been dramatic advances in knowledge and in the equipment available to skilled workers since that time.

Many cases are decided on whether the claimed subject matter was obvious to try and whether there was a reasonable expectation of success. The relevant approach was summarized by Lord Justice Kitchin in the following terms (MedImmune Ltd. v. Novartis Pharmaceuticals Ltd. ([2012] EWCA Civ 1234)):

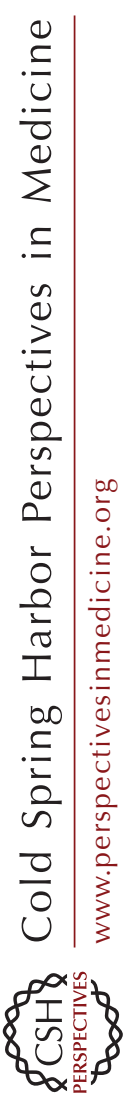

One of the matters which it may be appropriate to take into account is whether it was obvious to try a particular route to an improved product or process. There may be no certainty of success but the skilled person might nevertheless assess the prospects of success as being sufficient to warrant a trial. In some circumstances this may be sufficient to render an invention obvious. On the other hand, there are areas of technology such as pharmaceuticals and biotechnology which are heavily dependent on research, and where workers are faced with many possible avenues to explore but have little idea if any one of them will prove fruitful. Nevertheless, they do pursue them in the hope that they will find new and useful products. They plainly would not carry out this work if the prospects of success were so low as not to make them worthwhile. But denial of patent protection in all such cases would act as a significant deterrent to research.

For these reasons, the judgments of the courts in England and Wales and of the Boards of Appeal of the EPO often reveal an enquiry by the tribunal into whether it was obvious to pursue a particular approach with a reasonable or fair expectation of success as opposed to a hope to succeed. Whether a route has a reasonable or fair prospect of success will depend upon all the circumstances including an ability rationally to predict a successful outcome, how long the project may take, the extent to which the field is unexplored, the complexity or otherwise of any necessary experiments, whether such experiments can be performed by routine means and whether the skilled person will have to make a series of correct decisions along the way....

It has been pointed out in a number of decisions of the Boards of Appeal in the field of biotechnology that when evaluating the attitude of a skilled person, "hope to succeed," which is linked to a wish for a result to be achieved, differs from "reasonable expectation of success," which is linked to the ability to reasonably predict, based on the particular technical circumstances, a successful outcome of the postulated step within acceptable time limits. The latter requires scientific evaluation of the real difficulties, if any, relating to that step. ${ }^{19}$ It has been emphasized that the existence of such difficulties has to be supported by documentary and/ or experimental evidence. ${ }^{20}$

Chymosin $^{21}$ provides an early example in which inventive step was denied. A skilled person could have expected to be able to clone and express the relevant gene straightforwardly. Although much work was required, there were no daunting unsolved problems. In a similar case, ${ }^{22}$ the isolation of bile transporter cDNA from hamster ileal cells was held not to involve an inventive step. The skilled person knew from a primary reference that the relevant DNA could be isolated from the ileal cells, and the prior art disclosed straightforwardly how to do so. No problem had been identified that would have prejudiced a skilled person against starting the research, and no difficulties had subsequently arisen that demanded more than routine skill.

Factors weighing against an obviousness finding have included unavailability of a suitable starting point for obtaining probes, one possible reason being uncertainty as to the structure of the target protein. ${ }^{23}$ An example is provided by insulin-like binding protein, which prior to the invention was known to be of molecular weight 45-50 kDa. However, SDS polyacrylamide gel electrophoresis (SDS-PAGE) revealed major and minor bands. It was not known whether they resulted from contamination, a difference in glycosylation, or association of two components into a complex. Difficulties facing the inventors included lack of knowledge

\footnotetext{
${ }^{19} \mathrm{~T} 0207 / 94$ (Human beta-interferon).

${ }^{20} \mathrm{~T} 1069 / 08$ (Desaturase/CALGENE) at [15].

${ }^{21} \mathrm{~T}$ 0386/94 (Chymosin/UNILEVER).

${ }^{22}$ T 0769/03 (Ileal Bile Acid Transporter/WAKE FOREST).

${ }^{23} \mathrm{~T}$ 0637/97 (Binding protein/GENENTECH).
} 
of the complete amino acid sequence, lack of knowledge about the relationship between the major and minor band components, and the degeneracy of the only existing cloning sequence. The skilled person would not have been able to anticipate whether further elucidation of the amino acid sequence of either component would have revealed sequences of internal fragments of a lower level of degeneracy suitable for producing adequate probes, and there was therefore no reasonable expectation of success.

In a further example, in which the target protein was a thermally stable Taq polymerase, the available enzymes differed in purity but a highly pure protein was needed for antibody preparation and successful screening. In the circumstances, isolating cDNA encoding the polymerase would have been a matter of luck. $^{24}$

In another example relating to tissue factor protein (TFP), ${ }^{25}$ although placenta tissue was a common starting material for the purification of TFP, it could not provide suitable mRNA because of faulty splicing. Adipose tissue could provide TFP mRNA but only in low abundance and at large size $(2350 \mathrm{bp})$. The average size of cDNA obtainable by methods then available was $\sim 600 \mathrm{bp}$, and reverse transcription of the full-length molecule could not be expected. To overcome this difficulty and maximize the chance that cloned DNAwould be of full length, the inventors therefore departed from the normal practice of using probes that hybridized to the $5^{\prime}$ end of the cDNA and instead used a probe that hybridized to an internal part of the cDNA. The board was satisfied that there had been difficulties that required inventive skill to overcome.

In yet a further example, ${ }^{26}$ the invention related to a newly discovered polypeptide of the interleukin-17 (IL-17) cytokine family and a nucleotide sequence encoding it. It was held that as several members of the IL-17 family iso-

${ }^{24} \mathrm{~T} \quad 0340 / 00 \quad$ (Thermostable enzyme/HOFFMANN-LA ROCHE).

${ }^{25} \mathrm{~T}$ 0351/01 (Tissue Factor Protein/GENENTECH).

${ }^{26} \mathrm{~T}$ 1165/06 (IL-17 related polypeptide/SCHERING). lated from mouse or human cells had already been described, it was obvious to try to isolate additional members of that family. However, immunoscreening would have been time-consuming, difficult because members of the family had low overall similarity at the primary structure level, and uncertain. In vitro or in silico screening of DNA libraries or databases would also have been difficult and uncertain. Even though the novel polypeptide exhibited features that allowed it to be ascribed it to the IL-17 family, significant sequence differences in some domains and the complete absence of other domains were neither known nor foreseeable by the skilled person at the filing date, and were only revealed after the novel polypeptide had been identified by the inventors. A screening strategy designed on the basis of the domain information provided in the prior art would, most probably, have failed to "fish out" the IL17 sequence so that a reasonable expectation of success could not be assumed, and accordingly an objection of lack of inventive step had not been established.

In acknowledging inventive step for the use of a 185 delAG $\rightarrow$ ter39 mutation in the BRCA1 gene for the detection of cancer, ${ }^{27}$ the EPO Board of Appeal held that the technical problem to be solved was the provision of a mutation that allowed the development of an effective screening for inherited breast and ovarian cancer, and it was satisfied that this problem had been solved by the particular mutation of the method claimed. It then set out its conclusions as follows:

The Board is therefore convinced that, in view of the disclosure in document D1, the skilled person, taking a conservative attitude, would not have reasonably expected to successfully identify a mutation that allows the development of an effective screening for inherited breast and ovarian cancer within acceptable time limits. From the skilled person's perspective at the fourth priority date of the patent in suit, finding such a mutation would not only involve a substantial amount of "challenging" work, but would also

${ }^{27}$ T 0666/05 (Mutation/UNIVERSITY OF UTAH). 
P. Cole

require a "lucky strike," which could in no way be predicted on the basis of document D1.

\section{PRIORITY AND ADDED SUBJECT MATTER}

Those who draft specifications claiming new nucleotide or protein sequences should be aware of the severity with which changes from an earlier disclosure are examined both from the standpoint of priority and from the standpoint of amendment during examination ( $\mathrm{Ar}-$ ticle 123(2) EPC).

The difficulties that an applicant may face are illustrated by an EPO opposition ${ }^{28}$ concerning the $B R C A 1$ gene in which the subject matter claimed was a variant of what had been disclosed in a priority application and in a subsequent published paper. The applicants had filed a U.S. priority application with an incorrect or "deviated" nucleotide coding sequence that was subsequently found to have 15 errors. Of these, six were silent deviations not leading to amino acid exchange and nine led to exchange of amino acids in the listed sequence. The inventors published a paper disclosing this "deviated" sequence. They subsequently filed a further U.S. application disclosing a corrected sequence and then applied to the EPO with a specification listing and claiming the corrected sequence but omitting the earlier deviated sequence. If the claim to the corrected sequence was not entitled to priority, then according to a decision of the Enlarged Board of Appeal of the EPO, ${ }^{29}$ the published paper was citable prior art, and in particular it was citable against claims to subject matter not disclosed in the priority document. It was noted by the Enlarged Board in its opinion that the Court of Appeals for the Federal Circuit (CAFC) had made a ruling to the same effect (In re Gosteli (10 U.S.P.Q.2d 1614) (1989)).

In a number of earlier decisions, the board had taken the position that entitlement to priority is lost when a sequence is changed, the reasons being that there must be an individual-

${ }^{28} \mathrm{~T} 1213 / 05$ (Breast and ovarian cancer/UNIVERSITY OF UTAH).

${ }^{29} \mathrm{G} 0003.93$ (Priority interval/PRESIDENT'S REFERENCE). ized disclosure of the specific molecule subsequently claimed and that: ${ }^{30}$

It is also the board's opinion that, based on a disclosure of a "wrong" nucleotide or amino acid sequence in the priority document-independently of the reasons for the possible mistakes, either arising from unintended sequencing or typing errors or else arising from a conscious choice to file an application at a very early stage and thus, comprising doubtful or incomplete data-it would not be fair to acquire a right over a broad area from which, only later on, the "correct" sequence might be selected and disclosed in a patent application. The possible advantages conferred by such a practice would only encourage and, in the long term, lead to a mischievous use of priority rights.

The issue before the board was whether the specific technical situation in BRCA1 required a more pragmatic approach. The patentees pointed out that the corrected sequence had $99.73 \%$ identity with the originally disclosed deviated sequence; that DNA sequencing was a measurement method that regularly produced experimental errors and was unable to produce $100 \%$ accurate data; and that although the accuracy of so-called finished sequences should be no less than $99.99 \%$, preliminary results of sequencing projects were very useful, so that such "working drafts" having sequence accuracy between $90 \%$ and $99 \%$ were also publishable. Legal certainty for third parties, they argued, was a function of the technology it referred to and could not be higher than experimental certainty. Furthermore, the underlying technical problem was the provision of the isolated $B R C A 1$ gene as a tool to diagnose a predisposition to breast or ovarian cancer. The sequence deviations between the priority document and the application as filed were irrelevant for solving that problem because in more than 180,000 tests carried out over a period of 12 years the differences had never exhibited any relevance for the diagnosis of breast or ovarian cancer predisposition. As soon as the inventors had published the "deviated" sequence, other scientists, using that sequence, were able to provide accurate detection

${ }^{30} \mathrm{~T}$ 0070/05 (Apoptosis receptors/GENENTECH) at [20]. 
of BRCA 1 mutations and diagnosis of predisposition to breast and ovarian cancer.

In rejecting the above arguments, the board emphasized that the claims at issue referred to a DNA sequence coding for a specific polypeptide and the relevant issue was structural difference. On this issue there was no room for distinguishing between deviations that were relevant to the function and effect of the sequence and those that were not. ${ }^{31}$ That principle has been followed in previous decisions concerning DNA technology, and the right to priority had been denied where the sequence deviations between the priority document and the patent were situated in the noncoding region. ${ }^{32}$ The existing case law was uniform and definite, and no reason had been established in deviating from it.

In the outcome, because priority had been lost, the inventors' published paper was noveltydestroying, and although the patent was maintained, it was only with limited claims covering certain nucleic acid probes.

In contrast, a more lenient approach was adopted where the claimed subject matter involved not the sequence itself but its use. When the claimed subject matter concerned the detection of frameshift mutations in the BRCA1 gene $^{33}$ or a single nucleotide germline mutation, ${ }^{34}$ the sequence differences did not have any impact on the actual invention claimed. The mutation to be detected was exactly the same irrespective of whether the deviated or the corrected sequence was used as a reference, and hence priority was allowable.

\section{CONCLUSIONS}

It will be appreciated that applicants can continue to claim naturally occurring sequences and indeed purified natural products in the EPO and to claim at least nonhuman sequences before the national patent offices of the contracting states.

\footnotetext{
${ }^{31} \mathrm{G} 2 / 98$ supra at [9].

${ }^{32} \mathrm{~T}$ 0351/01 (Tissue Factor Protein/GENENTECH) at [17].

${ }^{33} \mathrm{~T}$ 0080/05 (Method of diagnosis/UNIVERSITY OF UTAH).

${ }^{34} \mathrm{~T}$ 0666/05 (Mutation/UNIVERSITY OF UTAH).
}

From the specification-drafting standpoint, U.S. applicants should continue to provide at least statements of invention (and desirably claims) directed to genetic sequences in the same way that they would have done prior to the decision in Myriad. If such statements and/or corresponding claims are omitted from the application at the time of filing, then it is unlikely that an amendment to add them will be permitted by the EPO, the reason being that such addition would amount to a generalization not supported by the application as filed and hence impermissible under Article 123(2) EPC. If the necessary generalized and detailed claim language is omitted from a priority document, then following the stringent criteria set out by the EPO Enlarged Board of Appeal, ${ }^{35}$ priority may not be recognized.

To minimize priority and added subject matter problems, when a sequence listing is given, it is important to explain the accuracy with which it has been determined and to draft claims or statements of invention that cover variants within the foreseeable range of experimental error. It should be borne in mind, however, that such generic coverage cannot provide individual disclosure for particular variant species. When a sequence is determined with greater accuracy between an initial U.S. filing and a subsequent Patent Cooperation Treaty (PCT) or EPO filing, the safe course is to include both the original and the corrected versions in the international or European specification as filed.

It has been suggested by Cole $(2013,2014)$ that the ruling of the U.S. Supreme Court in Myriad, when correctly interpreted, may be narrower than supposed and may be avoidable if a naturally occurring sequence provides new utility of practical importance. However, new U.S. Patent and Trademark Office (USPTO) patenteligibility guidelines ${ }^{36}$ (Hirshfeld 2014) argu-

\footnotetext{
${ }^{35} \mathrm{G} 2 / 98$ (Requirement for claiming priority of the "same invention").

${ }^{36}$ For example, a claim to a stable energy-generating plasmid that provides a hydrocarbon degradative pathway would be regarded as ineligible because the claim recites a plasmid that is naturally occurring, and thus the claim as a whole recites
} 
P. Cole

ably fall into the error of gold-plating rather than faithfully applying recent opinions of the U.S. Supreme Court insofar as they introduce the criterion of marked structural difference. The Myriad decision as at present being interpreted by the USPTO leaves the United States in the singular position identified by Justice Ginsburg during the oral argument in that case and as explained above is arguably at variance with the law and practice of the EPO, the national laws of the EPC contracting states, and possibly also the provisions of Article 27 of the TRIPS Agreement. $^{37}$

\section{REFERENCES}

Ann C. 2006. Patents on human gene sequences in Germany: On bad lawmaking and ways to deal with it. German Law J 7: 279-292. www.germanlawjournal.com/index .php?pageID $=11$ \&artID $=716$.

Cole P. 2013. The unacknowledged role of section 112 in the Myriad decisions. patents4life. CIPA J 12: 708-712.

Cole P. 2014. Myriad, an obvious and patent-friendly interpretation. CIPA J 6: 335-337.

Gold ER, Carbone J. 2010. Myriad genetics: In the eye of the policy storm. Genet Med 12: S39-S70.

Hirshfeld AH. 2014. Procedure For subject matter eligibility analysis of claims reciting or involving laws of nature: Natural principles, natural phenomena, and/or natural products. www.uspto.gov/patents/law/exam/myriad-mayo_ guidance.pdf.

nothing more than a natural product. The guidance has been the subject of public debate, and comments submitted to the USPTO by intellectual property organizations and other associations (18), academic and research institutions (7), law firms (6), companies (9), and individuals (42) can be found on a dedicated web page at www.uspto.gov/patents/law/ comments/myriad-mayo_guidance_comments.jsp. The position remains for the time being that isolated sequences that occur in nature are not patent-eligible.

${ }^{37}$ In comments filed at the USPTO on July 31,2014 , the American Bar Association advised that "The Guidance should also apply Myriad and Mayo not only in the proper context of the remainder of the patent statute, but also in the context of the International treaty obligations of the United States, particularly the Agreement on Trade-Related Aspects of Intellectual Property Rights. The ABA IPL takes no position on whether the application of the Guidance will lead to inventions being denied patent eligibility in violation of TRIPS. But, as written the Guidance and the exclusions for patent eligibility under TRIPS do not appear to be consistent and could lead to such allegations when inventions are denied patent eligibility under the Guidance. Further, the United States should remain a strong advocate of IP rights globally and should ensure that the USPTO Guidance is applied consistently with the letter and principles embodied in TRIPS." Other comments on the dedicated web page make the same point. 


\section{$\&_{\mathrm{CSH}}^{\infty} \&$ Cold Spring Harbor

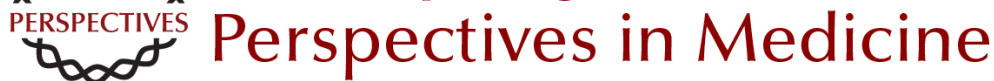

\section{Patentability of Genes: A European Union Perspective}

Paul Cole

Cold Spring Harb Perspect Med 2015; doi: 10.1101/cshperspect.a020891 originally published online October 16, 2014

\section{Subject Collection Intellectual Property in Molecular Medicine}

Patentability of Stem Cells in the United States Sarah E. Fendrick and Donald L. Zuhn, Jr.

Inventorship and Authorship Antoinette F. Konski and Linda X. Wu

The Patentability of Stem Cells in Australia Jenny Petering and Prue Cowin

Impact of America Invents Act on Biotech Intellectual Property

Amanda Murphy, Michael Stramiello, Jonathan Stroud, et al.

Introduction to Intellectual Property: A U.S.

Perspective

Amanda Murphy, Michael Stramiello, Stacy Lewis, et al.

The Role of Regulatory Agencies and Intellectual Property: Part I

Kevin E. Noonan

Canada's Patented Medicines (Notice of Compliance) Proceedings and Intellectual

Property

Henry Bian and Conor McCourt

Patentability of Genes: A European Union

Perspective

Paul Cole
The Impact of Myriad on the Future Development and Commercialization of DNA-Based Therapies and Diagnostics

Michele Wales and Eddie Cartier

Protecting Traditional Knowledge Related to

Biological Resources: Is Scientific Research

Going to Become More Bureaucratized?

Prashant Reddy and Malathi Lakshmikumaran

Protecting Trade Secrets in Canada

Noel Courage and Janice Calzavara

Inherent Anticipation in the Pharmaceutical and

Biotechnology Industries

Michael Goldman, Georgia Evans and Andrew Zappia

The Role of Regulatory Agencies and Intellectual

Property: Part II

Kevin E. Noonan

Baseball Bats and Chocolate Chip Cookies: The Judicial Treatment of DNA in the Myriad Genetics Litigation lan Binnie and Vanessa Park-Thompson

The Impact of Myriad and Mayo: Will

Advancements in the Biological Sciences $\mathrm{Be}$

Spurred or Disincentivized? (Or Was Biotech

Patenting Not Complicated Enough?) Jennifer Gordon

Trade Secrets in Life Science and Pharmaceutical Companies

Tara Nealey, Ronald M. Daignault and Yu Cai

For additional articles in this collection, see http://perspectivesinmedicine.cshlp.org/cgi/collection/ 